\title{
Evaluation of Bio Control Efficacy of Pseudomonas fluorescens AS15 against Banded Leaf and Sheath Blight Pathogen (Rhizoctonia solani) in different Carbon and Nitrogen Sources
}

\author{
Anjul Rana* and Manvika Sahgal \\ Department of Microbiology, G.B. Pant University of Agriculture and Technology, \\ Pantnagar, 263145, Uttarakhand, India \\ *Corresponding author
}

\section{A B S T R A C T}

Keywords

Banded leaf and sheath blight,

Pseudomonas

fluorescens,

Bio control,

Rhizoctonia solani,

Maize, Antibiotics.

Article Info

Accepted:

19 May 2017

Available Online:

10 June 2017
Banded leaf and sheath blight disease causes major yield loss of maize. Bio control agents control the disease without any harmful effect. Pseudomonas fluorescence is a potential bio control agent due to production lytic enzymes and various secondary metabolites such as DAPG, Phenazine, pyoluteorin, pyrollnitrin. In dual plate assay $P$. fluorescens AS15 culture and it supernatant inhibit the growth of Rhizoctonia solani with $35.5 \%$ and $86.6 \%$ percent inhibition respectively. The $\lambda$ max for DAPG was detected in all carbon and nitrogen sources except tween 20 and Pyoluteorin $\lambda$ max was also detected in all carbon and nitrogen sources except arabinose and tween 20 . Whereas $\lambda$ max for pyrrolnitrin was detected in the presence of aserine, arginine, L-phenylalanine, threonine, arabinose, ducitol, sucrose, glucose and galactose. The best sources for the growth of $P$. fluorescens AS15 were sucrose and glucose. Good percent inhibition of $P$. fluorescens AS15 against Rhizoctonia solani was observed in the presence of inulin, dulcitol, glucose, galactose, serine and sucrose. In present study we conclude that glucose is the best carbon source for the growth, production of antibiotic and antagonistic behaviour of $P$. fluorescens AS15.

\section{Introduction}

Among all diseases of maize, Banded Leaf and Sheath Blight (BL and $\mathrm{SB}$ ) disease is considered as most damaging (Payak and Sharma, 1985). BL and SB is disease caused by Rhizoctonia solani. It leads to yield loss of upto $40 \%$. Banded Leaf and sheath blight is one of the major disease of maize causes upto $40 \%$ yield loss. Infected leaves and sheaths that are discoloured and there is appearance of irregular to roundish spots on both the surfaces (Saxena, 1997). BL and SB disease be controlled by two main methods, chemical and biological. The use of chemical pesticides is hazardous and environmentally damaging. Biological control is an important control measure because it controls the disease without any harmful effects. Pseudomonas is ideal antagonists as they have ability to produce various inhibitory compounds (Schroth and Hancock, 1982). Bio control agent which isolates from the rhizosphere of 
maize performed as better bio control agent against maize pathogen because it easily colonize on the plant root and survive for long term. This study aimed to finding best carbon and nitrogen sources that would allow maximum growth and antibiotic production of $P$. fluorescens AS15 for improving its bio control potentiality against banded leaf and sheath blight pathogen. The growth medium has a profound effect on growth and active metabolite production. The accurate incorporation of nutrients enhanced growth as well as antagonistic behavior of bio control agents (Slininger et al., 1996).

\section{Materials and Methods}

\section{Isolation of culture}

Ten different bacterial strains were isolated using King's B medium from rhizospheric soil of maize obtained from CRC GBPUA and $\mathrm{T}$ Pantnagar. Out of ten, only one bacterial strain (AS15) was selected as bio control agent on the basis of its antagonistic potential. Banded leaf and sheath blight pathogen (AS5) was isolated from infected leaves of maize and evaluated for its virulence by pathogenicity testing.

\section{Pathogenecity test of fungal pathogen}

Isolated Rhizoctonia solani used in this study was assessed for its pathogenic potential through in vivo assay on maize plants carried out in a glasshouse. Pathogenicity test was conducted in a completely randomized (CR) design with four replicates.

The $5 \mathrm{~kg}$ capacity pots were filled with sterilized soil and three surface sterilized seed were sown in each pot at temperature range from $30-40^{\circ} \mathrm{C}$ with high humidity. Pathogen was inoculated on 30 day old maize plant between the stem and leaf sheath (Vidhyasekaran et al., 1997). The plants were observed for development of disease symptoms and infected leaves were used for re-isolation of Rhizoctonia solani.

\section{In vitro antagonism assay}

Pseudomonas fluorescens AS15 was screened for in vitro antagonistic activity against Rhizoctonia solani f. sp. sasakii by dual culture plate assay (Anith and co-workers, 2003) using both whole cell and cell free supernatant against phytopathogenic fungi. A disc of Rhizoctonia solani f. sp. sasakii growing on PDA was placed at the centre of the Petri plate. Log phase culture of Pseudomonas fluorescens AS15 was streaked directly at the edge of the Petri plate containing 1/4th strength of King's B + PDA. Log phase culture of bio control agent was centrifuged and cell free supernatant used for in vitro antagonistic assay by disc method. Plates were incubated at $28 \pm 1^{\circ} \mathrm{C}$ for three days and examined for inhibition of fungus by the bacterium. Thereafter, sizes of inhibition zone of fungus (in $\mathrm{cm}$ ) were determined by measuring the distance between the fungal mycelia and the bacterial culture. The percent inhibition was calculated as described by Hagedorn et al., (1989). The percent inhibition (PI) was calculated by the following formula:-

$\mathrm{PI}=\frac{\mathrm{C}-\mathrm{T}}{\mathrm{C}} \times 100$

Where, $\mathrm{C}$ is the growth of test pathogen (in $\mathrm{cm})$ in the absence of the antagonistic strain, $\mathrm{T}$ is the growth of test pathogen (in $\mathrm{cm}$ ) in the presence of the antagonistic strain.

\section{Antibiotic production assay}

Stock solution $10 \%$ of each carbon and all nitrogen sources were prepared in sterilized TDW or $1 \mathrm{~N} \mathrm{NaOH}$ and filtered through 0.22 $\mu \mathrm{m}$ bacteriological filter and stored at $4^{\circ} \mathrm{C}$. The production of antibiotics was assayed in 
liquid basal medium $\mathrm{M} 1 \quad\left(\mathrm{~K}_{2} \mathrm{HPO}_{4}=1 \mathrm{~g}\right.$, $\mathrm{KH}_{2} \mathrm{PO}_{4}=1 \mathrm{~g}, \quad \mathrm{FeCl}_{3} .6 \mathrm{H}_{2} \mathrm{O}=0.01 \mathrm{~g}, \quad \mathrm{MgSO}_{4} .7$ $\mathrm{H}_{2} \mathrm{O}=0.2 \mathrm{~g}, \quad \mathrm{CaCl}_{2}=0.1 \mathrm{~g}, \quad\left(\mathrm{NH}_{4}\right)_{2} \quad \mathrm{SO}_{4}=1 \mathrm{~g}$, Agar $=15 \mathrm{~g}$ ) amended with different carbon and nitrogen sources separately with three replications. Carbon and nitrogen sources were added in Erhlenmeyer flask containing $40 \mathrm{ml} \mathrm{M} 1$ basal medium to the final concentration of $2 \%$. Each flask was inoculated with single colony of $P$. fluorescens AS15 and incubated at $28 \pm 1{ }^{\circ} \mathrm{C}$, $120 \mathrm{rpm}$ on rotary shaker.

The sample were withdrawn twice at 36 and $72 \mathrm{~h}$ respectively and analysed for growth and antibiotic production. Growth was measured at $600 \mathrm{~nm}$ and antibiotics such as DAPG, pyoluteorin, pyrollnitrin were detected with its $\lambda$ max at 225, 227 and $325 \mathrm{~nm}$ respectively by UV-Visible spectrophotometer. Same samples were also analysed for in vitro antagonistic activity against Rhizoctonia solani.

\section{Results and Discussion}

\section{Characterization of Microbial Isolate}

Bacterial strain AS15 is gram negative (Fig. 1a), short rod and appeared as white mucoid colony on King's B Agar (Fig. 1b). It molecularly characterized as Pseudomonas fluorescens on the basis of 16SrDNA sequencing. It possessed antifungal attributes viz., production of fungal cell wall lytic enzymes such as chitinase, lipase, cellulase, $\beta-1,3$-glucanase and protease as well as antibiotics (2, 4 diacetylphloroglucinol, pyoluteorin, pyrrolnitrin) (Rajwar, 2015).

Disease symptoms were appeared on leaf and sheath after $48 \mathrm{~h}$ of pathogen inoculation (Fig. 2) during pathogenecity test. Fungal mycelium initially appears white but turns brown after 4 days of incubation at $25 \pm 1^{\circ} \mathrm{C}$. It forms sclerotium that appears as dark brown color spots on the PDA plates (Singh and
Sharma, 1976; Maiti, 1978 and Akhtar et al., 2009). Vegetative hypha is branched near distal septum at angle of $90^{\circ}$, and constricted near the point of branching (Fig. 3).

\section{In vitro antagonism assay}

The whole cell culture and cell free supernatant of Pseudomonas fluorescens AS15 inhibits the fungal mycelium of Rhizoctonia solani in vitro. The percent inhibition with whole cell culture and cell free supernatant was $35.5 \%$ and $86.6 \%$ respectively. The higher percent inhibition in case of supernatant assay indicates that secondary metabolites produced by $P$. fluorescens AS15 play a significant role in inhibition (Fig. 4).

The medium components (carbon and nitrogen sources, their ratios, mineral factors) and conditions $(\mathrm{pH}$, temperature and agitation) used to grow bio control agents influence their growth as well as subsequent properties like secondary metabolite production (Zhang et al., 2005). The aim of the study was to find out carbon and nitrogen sources that provide maximum biomass production for Pseudomonas fluorescens strain AS15 and enhanced antibiotic production.

Antibiotic production and antagonistic behavior of $\boldsymbol{P}$. fluorescens AS15 against $\boldsymbol{R}$. solani with different amendment

All the three antibiotics, DAPG, pyrrolnitrin, pyoluteorin were detected in basal medium supplemented with glucose, galactose, Lphenylalanine, threonine and arginine. In glucose and galactose the production started at $36 \mathrm{~h}$ and continued till $72 \mathrm{~h}$. The production of DAPG was detected in basal medium incorporated with all carbon sources except tween 20. Pyoluteorin was detected in all carbon and nitrogen sources except arabinose and tween 20 (Table 1). 
Table.1 Influence of carbon and nitrogen source amendment in Liquid basal medium on Antibiotics production of Pseudomonas fluorescens AS15

\begin{tabular}{|c|c|c|c|c|c|c|c|}
\hline \multirow[t]{3}{*}{ S.No. } & \multirow[t]{3}{*}{ Carbon sources } & \multicolumn{6}{|c|}{ Detection of various antibiotics spectrophotometrically } \\
\hline & & \multicolumn{2}{|c|}{$\begin{array}{c}\text { DAPG } \\
\lambda \max 225\end{array}$} & \multicolumn{2}{|c|}{$\begin{array}{c}\text { Pyoleutorin } \\
\lambda \max 272\end{array}$} & \multicolumn{2}{|c|}{$\begin{array}{c}\text { Pyrolnitrin } \\
\lambda \max 325\end{array}$} \\
\hline & & 36h & $72 \mathrm{~h}$ & 36h & 72h & 36h & $72 \mathrm{~h}$ \\
\hline 1 & Serine & + & + & + & + & + & - \\
\hline 2 & Arginine & + & + & - & + & + & + \\
\hline 3 & Glutamic acid & - & + & - & + & - & - \\
\hline 4 & L-Phenyalanine & + & + & + & + & + & - \\
\hline 5 & L- Threonine & + & + & + & + & + & - \\
\hline 6 & L-Alanine & - & + & - & + & - & - \\
\hline 7 & Arabinose & + & + & - & - & + & + \\
\hline 8 & Inulin & + & + & + & + & - & - \\
\hline 9 & Adonitol & + & + & + & + & - & - \\
\hline 10 & Fructose & + & + & + & + & - & - \\
\hline 11 & Ducitol & + & + & - & + & + & + \\
\hline 12 & Sucrose & + & + & + & + & + & - \\
\hline 13 & Glucose & + & + & + & + & + & + \\
\hline 14 & Galactose & + & + & + & + & + & + \\
\hline 15 & Maltose & + & + & - & + & - & - \\
\hline 16 & Glycerol & + & + & + & + & - & - \\
\hline 17 & Ribose & + & + & + & + & - & - \\
\hline 18 & Dextrin & + & + & - & + & - & - \\
\hline 19 & T 20 & - & - & - & - & - & - \\
\hline 20 & T 80 & + & + & + & + & - & - \\
\hline
\end{tabular}

Table.2 Effects of different sources of carbon and nitrogen on growth and Antagonistic efficacy of Pseudomonas fluorescens AS15

\begin{tabular}{|c|c|c|c|}
\hline S.No. & $\begin{array}{l}\text { Name of carbon } \\
\text { source }\end{array}$ & $\begin{array}{c}\text { Zone of inhibition } \\
\text { (cm) }\end{array}$ & OD at $600 \mathrm{~nm}$ \\
\hline 1 & Control & $0.1 \pm 0.05$ & 0.01 \\
\hline 2 & Serine & $1.0 \pm 0.11$ & 1.8 \\
\hline 3 & Arginine & $0.7 \pm 0.05$ & 1.8 \\
\hline 4 & Glutamic acid & $0.3 \pm 0.10$ & 1.8 \\
\hline 5 & L- Phenyalanine & $0.9 \pm 0.10$ & 0.8 \\
\hline 6 & L- Threonine & $0.4 \pm 0.05$ & 1.4 \\
\hline 7 & L-Alanine & $0.6 \pm 0.10$ & 1.4 \\
\hline 8 & Arabinose & $0.9 \pm 0.10$ & 1.6 \\
\hline 9 & Inulin & $1.2 \pm 0.05$ & 1.6 \\
\hline 10 & Adonitol & $0.7 \pm 0.05$ & 1.6 \\
\hline 11 & Fructose & $0.9 \pm 0.10$ & 1.6 \\
\hline 12 & Dulcitol & $1.1 \pm 0.10$ & 1.8 \\
\hline 13 & Sucrose & $1.2 \pm 0.07$ & 2.0 \\
\hline 14 & Glucose & $1.3 \pm 0.05$ & 2.0 \\
\hline 15 & Galactose & $1.2 \pm 0.05$ & 1.6 \\
\hline 16 & Maltose & $0.6 \pm 0.10$ & 1.5 \\
\hline 17 & Glycerol & $0.8 \pm 0.07$ & 1.8 \\
\hline 18 & Ribose & $0.5 \pm 0.05$ & 1.3 \\
\hline 19 & Dextrin & $0.2 \pm 0.05$ & 1.2 \\
\hline 20 & Tween 20 & $0.0 \pm 0.00$ & 0.9 \\
\hline 21 & Tween 80 & $0.3 \pm 0.05$ & 0.4 \\
\hline
\end{tabular}

Cor- 0.35082 between zone of inhibition and OD at $36 \mathrm{hrs}$ 
Fig.1 Growth of $P$. fluorescens AS15 on King'S B medium (a) and gram staining (b)

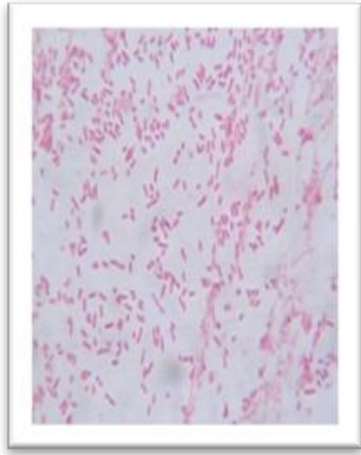

(a)

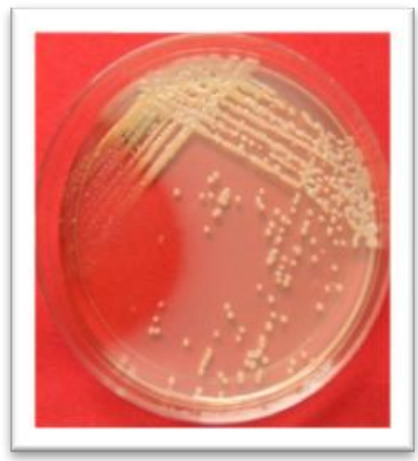

(b)

Fig.2 BL and SB disease symptom in maize plant inoculated with Rhizoctonia solani in pathogenecity test

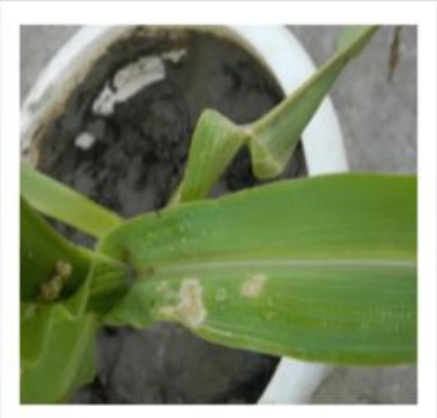

Fig.3 Lactophenol cotton blue stained Rhizoctonia solani hyphae (40X)

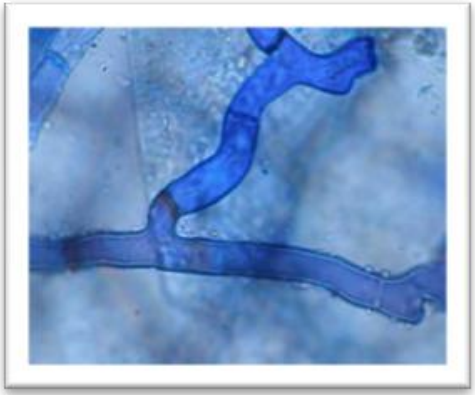

Fig.4 Inhibition of Rhizoctonia solani in the presence of supernatant of Liquid basal medium amended with glucose

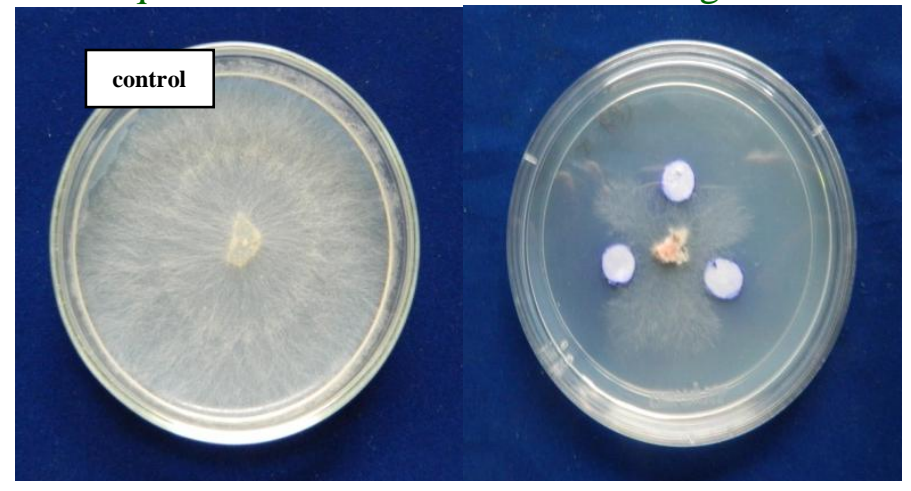


Single antibiotic pyrrolnitrin was detected when basal medium was supplemented with serine, arginine, L-phenylalanine, threonine, arabinose, ducitol, sucrose, glucose and galactose, at $36 \mathrm{~h}$ and its production continue till $72 \mathrm{~h}$ in the presence of arginine, arabinose, dulcitol, glucose and galactose.

Effects of carbon and nitrogen sources on growth and invitro antagonistic activity of P. fluorescens AS15

Adonitol, arabinose, arginine, dulcitol, fructose, galactose, glucose, glutamic acids, glycerol, serine, sucrose and Inulin are good sources for growth of Pseudomonas fluorescens AS15 as optical density ranges from 1.6- 2.0 at $600 \mathrm{~nm}$ (Table 2). Highest optical density 2.0 was observed in the presence of sucrose and glucose while 1.8 optical density was observed with serine, arginine, glutamic acid, dulcitol, glycerol, there was no correlation between the growth and in vitro antagonism of bio control agent against pathogen. P. fluorescens strain AS15 growing in basal medium amended with sucrose showed highest zone of inhibition against Rhizoctonia solani and fairly good inhibition was observed in the presence of inulin, dulcitol, glucose, galactose, serine and sucrose. In these sources the optical density of $P$. fluorescens AS15 was range from 1.6-2.0 at $600 \mathrm{~nm}$. The in vitro antagonism of $P$. fluorescens AS15 could be due to threshold population as well production of antibiotics. The use of these carbon and nitrogen sources in the basal medium enhanced the growth of P. fluorescens AS15 also enhanced its antagonistic potential.

In this study, the production of antagonistic substances did not correlate with population of the P. fluorescence AS15. Earlier Studies also reported that the rate of bacterial growth is not correlated with the antagonistic efficacy (Duffy and Defago, 2000; Costa et al., 2001).
In present study we conclude that glucose is the best carbon source for antibiotic production, growth and antagonistic behavior of $P$. fluorescens AS15.

The ability of Pseudomonas fluorescens AS15 to grow on large number of carbon and nitrogen sources facilitates its survival in different habitats and adaptation to changing environmental conditions. Metabolic versatility is linked to a flexible regulation of the metabolic pathways. Global regulation of metabolic networks participates in gene expression programmed under different situations (Sergio Sanchez et al., 2010). Metabolic regulatory processes that allow selection of preferred carbon sources is known as carbon catabolite repression (CCR) or catabolite repression control (CRC). CCR inhibits the expression of the pathways for nonpreferred compounds. CCR plays an important role in utilization of specific carbon, nitrogen sources and determining growth rate of bacterial species thus allowing for a flexible and reversible specialization for a particular carbon source (Gorke and Stulke, 2008).

\section{References}

Akthar, J., Kumar Jha, V. and Lal, H.C. 2009. Occurance of banded leaf and sheath blight of maize in Jharkhand with reference to diversity in Rhizoctonia solani. Asian J. Agri. Sci., 1: 32-35.

Anith, K., Radhakrishnan, N. and Manomohandas, T. 2003. Screening of antagonistic bacteria for biological control of nursery wilt of black pepper (Piper nigrum). Microbiol. Res., 158: 91-97.

Costa, E., Teixdo, N., Usall, J., Atares, E. and Vinas, I. 2001. Production of the biocontrol agent Pantoea agglomerans strain CPA-2 using commercial 
products and by-products. Appl. Microbiol. Biotechnol., 56: 367-371.

Duffy, B.K. and Defago, G. 2000. Controlling instability in gacS gacA regulatory genes during inoculants production of Pseudomonas fluorescens biocontrol strains. Appl. Environ. Microbiol., 66: 3142-3150.

Gorke, B. and Stulke J. 2008. Carbon catabolite repression in bacteria: many ways to make the most out of nutrients. Nat. Rev. Microbiol., 6: 613-624.

Hagedorn, C., Gould, W.D. and Bradinelli, R.T. 1989. Rhizobacteria of cotton and their repression of seedling disease pathogens. Appl. Environ. Microbiol., 55: 2793-2797.

Maiti, S. 1978. Two ear rots of maize from India. Plant Dis. Rep., 62: 1074-1076.

Payak, M.M. and Sharma, R.C. 1985. Maize diseases and their approach to their management. Trop. Pest Manage., 31: 302-310.

Rajwar, A. 2015. Characterization and evaluation of biocontrol efficacy of fluorescent pseudomonads against Banded Leaf and Sheath Blight Disease of Zea mays L. Ph.D. thesis, G. B. Pant University of Agriculture and Technology, Pantnagar.

Saxena, S.C. 1997. Banded leaf and Sheath blight of maize. In: Agnihotri, V.P.; Sarbhoy, A.K. and Singh, D.V. eds. Management of threatening plant diseases of national importance. Malhotra Publishing House, New Delhi, 31-50.
Schroth, M.N. and Hancock, J.G. 1982. Disease-suppressive soil and rootcolonizing bacteria. Sci., 216: 13761381.

Sergio Sanchez et al., 2010. Carbon sources regulation of antibiotic production. The J. Antibiotics, 63: 442-459

Singh, B.M. and Y.R. Sharma, 1976. Evaluation of maize germplasm to banded sclerotial disease and assessment of yield loss. Indian Phytopathol., 29: 129-132.

Slininger, P.J., Van Cauwenberge, J.E., Bothast, R.J., Weller, D.M., Thomashow, L.S. and Cook, R.J. 1996. Effect of growth culture physiological state, metabolites, and formulation on the viability, phytotoxicity and efficacy of the take-all biocontrol agent Pseudomonas fluorescens 2-79 stored encapsulated on wheat seeds. Appl. Microbiol. Biotechnol., 45: 391-398.

Vidhyasekaran, P., Ponmalar, T., Samiyappan, R., Velazhahan, R., Vimala, R., Ramanathan, A., Paranitharan, V. and Muthukrishnan, S., 1997a. Host specific toxin production by Rhizoctonia solani, the rice sheath blight pathogen. Phytopathol., 87: $1258 \pm 1263$.

Zhang, L.V., King, O.D., Wong, S.L, Goldberg, D.S, Tong, A.H, Lesage, G., Andrews, B., Bussey, H., Boone, C. and Roth, F.P. 2005. Motifs, themes and thematic maps of an integrated Saccharomyces cerevisiae interaction network. J. Biol., 4: 6.

\section{How to cite this article:}

Anjul Rana and Manvika Sahgal. 2017. Evaluation of Biocontrol Efficacy of Pseudomonas fluorescens AS15 against Banded Leaf and Sheath Blight Pathogen (Rhizoctonia solani) in Different Carbon and Nitrogen Sources. Int.J.Curr.Microbiol.App.Sci. 6(6): 1347-1353. doi: https://doi.org/10.20546/ijcmas.2017.606.158 